\title{
Enhanced anti-tumour activity of the combination of the novel MEK inhibitor WX-554 and the novel PI3K inhibitor WX-037
}

\author{
Emma J. Haagensen ${ }^{1}$ Huw D. Thomas ${ }^{1} \cdot$ Wolfgang A. Schmalix ${ }^{2}$. \\ Andrew C. Payne ${ }^{3} \cdot$ Lara Kevorkian $^{3} \cdot$ Rodger A. Allen $^{3} \cdot$ Paul Bevan $^{2} \cdot$ \\ Ross J. Maxwell ${ }^{1} \cdot$ David R. Newell $^{1}$
}

Received: 2 June 2016 / Accepted: 31 October 2016 / Published online: 11 November 2016

(C) The Author(s) 2016. This article is published with open access at Springerlink.com

\begin{abstract}
Purpose Tumours frequently have defects in multiple oncogenic pathways, e.g. MAPK and PI3K signalling pathways, and combinations of targeted therapies may be required for optimal activity. This study evaluated the novel MEK inhibitor WX-554 and the novel PI3K inhibitor WX-037, as single agents and in combination, in colorectal carcinoma cell lines and tumour xenograft-bearing mice.

Methods In vitro growth inhibition, survival and signal transduction were measured using the Sulforhodamine B, clonogenic and Western blotting assays, respectively, in HCT116 and HT29 cell lines. In vivo anti-tumour efficacy and pharmacokinetic properties were assessed in HCT116 and HT29 human colorectal cancer xenograft tumour-bearing mice.

Results The combination of WX-554 and WX-037 exhibited marked synergistic growth inhibition in vitro, which was associated with increased cytotoxicity and enhanced inhibition of ERK and S6 phosphorylation, compared to either agent alone. Pharmacokinetic analyses indicated that there was no PK interaction between the two drugs at low doses, but that at higher doses, WX-037 may delay
\end{abstract}

Electronic supplementary material The online version of this article (doi:10.1007/s00280-016-3186-4) contains supplementary material, which is available to authorized users.

David R. Newell

herbie.newell@ncl.ac.uk

1 Newcastle Cancer Centre, Northern Institute for Cancer Research, Paul O'Gorman Building, Medical

School, Newcastle University, Framlington Place, Newcastle-upon-Tyne NE2 4HH, UK

2 Wilex AG, Grillparzerstrasse 18, 81675 Munich, Germany

3 UCB Pharma Ltd, 208 Bath Road, Slough SL1 3WE, UK the tumour uptake of WX-554. In vivo efficacy studies revealed that the combination of WX-037 and WX-554 was non-toxic and exhibited marked tumour growth inhibition greater than observed with either agent alone.

Conclusion These studies show for the first time that combination treatment with the novel MEK inhibitor WX-554 and the novel PI3K inhibitor WX-037 can induce synergistic growth inhibition in vitro, which translates into enhanced anti-tumour efficacy in vivo.

Keywords PI3K · MEK · Combination · Synergy; Colorectal cancer

\section{Introduction}

The development of numerous targeted small molecule inhibitors represents an important and evolving new approach to cancer therapy. However, as tumours often have defects in multiple oncogenic signalling pathways, single agent anti-tumour activity is modest, and thus combinations of targeted agents are being investigated. Specifically, the MAPK pathway, a major proliferative pathway, and the PI3K pathway, a major survival pathway, are frequently activated in cancer and are being concomitantly targeted.

Many MEK inhibitors, such as PD 0325901 and selumetinib (AZD6244), have been developed to target the MAPK pathway and have shown potent growth inhibitory activity in experimental systems [1-4]. A novel orally available small molecule allosteric MEK inhibitor WX-554 (UCB1366554), which potently inhibits MEK1 and MEK2 with a half maximal inhibitory concentration $\left(\mathrm{IC}_{50}\right)$ of 4.7 and $11 \mathrm{nM}$, respectively, has been developed by Wilex and UCB Celltech. WX-554 has demonstrated 
marked inhibition of ERK1/2 phosphorylation in HT29 cells, and growth inhibition in a range of cell lines in vitro, and tumour growth delay or stasis in vivo, with increased sensitivity in BRAF or RAS mutant cells and tumours [5]. WX-554 has been shown to be safe and tolerable in a dose escalation study in healthy volunteers [6], and a recent Phase I study indicated that WX-554 has very good bioavailability and that it is able to inhibit MEK signal transduction in a dose-dependent manner [3, 7, 8]. WX-554 was investigated in a Phase Ib/II dose escalation study to determine safety and pharmacokinetics/pharmacodynamics in patients with solid tumours [7,9], which was terminated due to business, rather than clinical, reasons.

Targeting the PI3K/AKT pathway has been investigated with a range of PI3K inhibitors which can be isoformspecific inhibitors, pan class I inhibitors (e.g. pictilisib, GDC-0941) or dual PI3K/mTOR inhibitors (e.g. dactolisib, NVP-BEZ235), and promising anti-cancer efficacy has been reported in pre-clinical models [10-16]. Wilex and UCB Celltech have also developed a novel small molecule pan class I PI3K inhibitor, WX-037 (UCB1370037), from an indole series. WX-037 is a potent inhibitor of the $\alpha$ and $\delta$ isoforms of $\mathrm{PI} 3 \mathrm{~K}\left(\mathrm{IC}_{50}=4.1\right.$ and $2.4 \mathrm{nM}$, respectively) and a weaker inhibitor of the $\beta$ and $\gamma$ isoforms of PI3K and DNA-PK $\left(\mathrm{IC}_{50}=69,36\right.$ and $28 \mathrm{nM}$, respectively) with no detectable inhibition of mTOR $\left(\mathrm{IC}_{50}=>20,000 \mathrm{nM}\right)$. In pre-clinical studies, WX-037 demonstrated strong inhibition of AKT phosphorylation, and promising growth inhibition in a range of cell lines in vitro, and tumour growth delay or stasis in vivo, with greater sensitivity observed in PIK3CA mutant or PTEN null cells and tumours [5]. WX-037 was investigated in a Phase I dose escalation study to investigate its safety, pharmacokinetics, pharmacodynamics and clinical activity in patients with solid tumours; however, this trial was also terminated due to business reasons $[9,17]$.

Previous studies have shown that concomitant inhibition of the PI3K and MAPK pathways by PI3K and MEK inhibition yields promising anti-cancer effects in vitro and in vivo [2, 18-26], and the combination of WX-554 and WX-037 demonstrated synergy in vitro and increased efficacy in vivo [5]. Consequently, the Phase I trial of WX-037 was designed not just to investigate the efficacy of single agent WX-037, but also the combination of WX-554 and WX-037 [9].

The aim of this study was to determine the in vitro and in vivo activity of the novel MEK inhibitor WX-554 and the novel PI3K inhibitor WX-037, alone and in combination, in colorectal carcinoma cell lines and tumour xenograft-bearing mice. These colorectal carcinoma cell lines (HT29 and HCT116) were used as they both contain KRAS/RAF and PI3K pathway mutations. The first objective was to determine the in vitro potency and efficacy of the compounds, alone and in combination, by measuring growth inhibition using an SRB assay, cytotoxicity via a clonogenic assay and cell signalling by Western blotting, and to investigate if the effects of the combinations on cell growth were synergistic, additive or antagonistic using median effect analyses. These results were then used to design in vivo experiments to investigate the pharmacokinetic profile of the compounds and their efficacy, alone and in combination.

\section{Methods}

\section{Ethics statement}

All in vivo experiments were reviewed and approved by the Newcastle University (UK) animal welfare committee and were performed according to the guidelines for the welfare and use of animals in cancer research [27] and national law, under project license (PPL60/4442) issued by the UK Government Home Office under the animals (scientific procedure) act 1986.

\section{Inhibitors}

The MEK inhibitor WX-554 and the PI3K inhibitor WX-037 were kindly supplied by Wilex, Munich, Germany. For in vitro studies, the inhibitors were dissolved in anhydrous dimethyl sulphoxide (DMSO) and were stored frozen under light-protected conditions at $-20{ }^{\circ} \mathrm{C}$. For in vivo studies, the MEK inhibitor WX-554 was dissolved in $0.9 \% \mathrm{NaCl}(\mathrm{w} / \mathrm{v}), 10 \mathrm{mM}$ Na-citrate $\mathrm{pH} 3.0(\mathrm{w} / \mathrm{v})$ and $0.2 \%$ Tween $20(\mathrm{v} / \mathrm{v})$ in sterile distilled water and the PI3K inhibitor WX-037 was suspended in SMEDDS (self-microemulsifying drug delivery system; 25\% Capmul MCM EP (glycerol monocaprylocaprate) (v/v), 37.5\% Tween 80 (polyoxyethylene (20) sorbitan monooleate) $(\mathrm{v} / \mathrm{v})$ and $37.5 \%$ PEG 400 (polyethylene glycol 400) (v/v)).

\section{Cell lines and reagents}

HCT116 and HT29 human colorectal cancer cells were obtained from the ATCC (American Type Culture Collection). All cell lines were grown in RPMI-1640 medium (supplemented with $10 \%(\mathrm{v} / \mathrm{v})$ foetal bovine serum, $1 \%$ $(\mathrm{v} / \mathrm{v})$ penicillin $(50 \mathrm{U} / \mathrm{ml})$ - streptomycin $(50 \mathrm{mg} / \mathrm{ml})$ and $2 \mathrm{mM} \mathrm{L-glutamine)}$ and were confirmed free of mycoplasma contamination by regular testing with Mycoalert (Cambrex, Iowa, USA).

\section{Animals}

Animal studies were all carried out using female athymic CD1 nude mice (Charles River, Kent, UK), implanted 
with HCT116 or HT29 xenografts $\left(1 \times 10^{7}\right.$ cells in $50 \mu \mathrm{l}$ media injected subcutaneously into the right flank), maintained and handled in isolators under specific pathogen-free conditions.

\section{Growth inhibition assay}

Exponentially growing cells were grown in media in 96-well format and were exposed to increasing concentrations of the single agent inhibitors WX-554 or WX-037, or WX-554 combined with WX-037 at $0.25,0.5,1,2$ or 4 times their half maximal growth inhibitory concentration $\left(\mathrm{GI}_{50}\right)$ in DMSO, or $0.5 \%$ DMSO alone, for $72 \mathrm{~h}$. Growth was then measured using the Sulforhodamine B (SRB) method and analysed as described previously [23]. The $\mathrm{GI}_{50}$ concentration was calculated based on a standard point to point curve with 1000 segments using GraphPad Prism software (California, USA). The data were analysed by median effect analysis using CalcuSyn software (Biosoft, Cambridgeshire, UK), which calculates the combination index of multiple drugs by an algebraic estimation algorithm.

\section{Cytotoxicity assay}

Exponentially growing cells were exposed to increasing concentrations of the single agent inhibitors WX-554 or WX-037, or $10 \mu \mathrm{M}$ of WX-554 combined with $10 \mu \mathrm{M}$ WX-037 in DMSO or $0.5 \%$ (v/v) DMSO alone for $72 \mathrm{~h}$ before harvesting and reseeding for colony formation. After growth for 10-14 days, colonies were fixed in methanol-acetic acid 3:1 (v/v) and stained with crystal violet $(0.4 \% \mathrm{w} / \mathrm{v})$. Colonies consisting of more than 50 cells were counted on an automated colony counter (Oxford Optronix, Oxford, UK). Two-tailed paired t tests were used to compare the different groups. Differences with a $p<0.05$ were considered statistically significant.

\section{Western blotting}

Cells were treated with WX-554 and WX-037 at 1 or 10 times the half maximal growth inhibitory concentration $\left(\mathrm{GI}_{50}\right)$ in DMSO, or $0.5 \%(\mathrm{v} / \mathrm{v})$ DMSO alone, for $24 \mathrm{~h}$. Western blots were prepared, probed with phospho-4EBP1 (Thr37/46) (\#2855), phospho-p44/42 MAPK (Thr202/ Tyr204) (\#4370), phospho-AKT (Ser473) (\#4060) or phospho-S6 ribosomal protein (Ser235/236) (\#4858) monoclonal antibodies obtained from Cell Signalling Technology (New England BioLabs (UK) Ltd, Hertfordshire, UK) and developed as described previously [23]. Blots were then stripped (100 mM 2-mercaptoethanol, 2\% (w/v) SDS and
$62.5 \mathrm{mM}$ Tris pH6.8 at $55{ }^{\circ} \mathrm{C}$ for $30 \mathrm{~min}$ ) and re-probed with the respective total monoclonal antibody (4EBP1 (53H11) (\#9644), p44/42 MAPK (ERK1/2) (\#4695), AKT (pan) (C67E7) (\#4691) or S6 ribosomal protein $(5 \mathrm{~g} 10)$ (\#2217)) obtained from Cell Signalling Technology (New England BioLabs (UK) Ltd, Hertfordshire, UK) and developed as described above.

\section{Pharmacokinetic (PK) studies}

Mice bearing HCT116 or HT29 human tumour xenografts

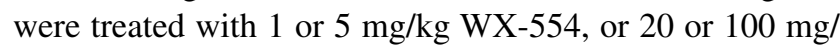
$\mathrm{kg} \mathrm{WX-037,} \mathrm{alone} \mathrm{or} \mathrm{in} \mathrm{combination,} \mathrm{and} \mathrm{were} \mathrm{bled} \mathrm{by}$ cardiac puncture under terminal anaesthesia at 6 or $24 \mathrm{~h}$ post-treatment ( 3 mice/time point). Blood was collected into heparinized tubes, and plasma was separated and stored at $-20{ }^{\circ} \mathrm{C}$ until analysed. Tumours were removed, snap frozen in liquid nitrogen and stored at $-80{ }^{\circ} \mathrm{C}$ prior to PK analyses. Samples were extracted with solid phase extraction (SPE) and analysed with high-performance liquid chromatography (HPLC) coupled with tandem mass spectrometry (MS/MS) by Wilex (Munich, Germany). The quantification limit for WX-554 was $1 \mathrm{ng} / \mathrm{mL}$ and within and between day variation was $<15 \%$. WinNonlin Software Version 4.0.1 (Pharsight Corporation, Peypin, France) was used for PK/PD modelling and non-compartmental analysis. Paired $t$ tests were used to compare the different treatment groups, and differences with a $p$ value $\leq 0.05$ were considered statistically significant.

\section{Determination of anti-tumour activity}

Mice bearing HCT116 human tumour xenografts were randomized into treatment groups and then treated by oral gavage with either the vehicle $(10 \mathrm{ml} / \mathrm{kg}), 2 \mathrm{mg} / \mathrm{kg}$ WX-554, $50 \mathrm{mg} / \mathrm{kg} \mathrm{WX-037} \mathrm{or} \mathrm{the} \mathrm{combination} \mathrm{of} 2 \mathrm{mg} /$ $\mathrm{kg} \mathrm{WX}-554$ and $50 \mathrm{mg} / \mathrm{kg} \mathrm{WX-037} \mathrm{once} \mathrm{daily} \mathrm{for} 14$ days. Tumour volume was monitored by calliper measurement using the equation $a^{2} \times b / 2$, where $a$ is the smallest measurement and $b$ the largest. Data are presented as median relative tumour volumes (RTV), where the tumour volume in each mouse on the initial day of treatment (day 0) is assigned an RTV value of 1 . The time to RTV4 for each individual tumour was calculated based on a standard point to point curve with 1000 segments using GraphPad Prism software (CA, USA). Mann-Whitney U tests were used to compare the different groups, i.e., the control versus each treatment group, the single agents versus each other and each single agent versus their combination. Differences with a $p$ value $\leq 0.05$ were considered statistically significant. 


\section{Results}

\section{The PI3K inhibitor WX-037 and the MEK inhibitor WX-554 are synergistic and exhibit increased cytotoxicity in combination in vitro}

The growth inhibitory activity of the PI3K inhibitor WX-037 and the MEK inhibitor WX-554, as single agents, in HCT116 and HT29 cells was measured using the SRB assay (Supplementary Figure 1). Both drugs induced over $65 \%$ growth inhibition in both the colorectal cell lines. The results were used to determine the half maximal growth inhibitory $\left(\mathrm{GI}_{50}\right)$ concentration of the drugs after 72-h exposure. The MEK inhibitor WX-554 was found to have $\mathrm{GI}_{50}$ values of 38 and $4.3 \mathrm{nM}$, whereas the PI3K inhibitor WX-037 was less potent with $\mathrm{GI}_{50}$ values of 2934 and $112 \mathrm{nM}$ in the HCT116 and HT29 cell lines, respectively (Supplementary Figure 1).

Studies were then performed to determine the effect of combining the PI3K and MEK inhibitors on colorectal carcinoma cell growth over $72 \mathrm{~h}$. WX-037 and WX-554 were used alone at $0.25 \mathrm{x}, 0.5 \mathrm{x}, 1 \mathrm{x}, 2 \mathrm{x}$ and $4 \mathrm{x}$ their respective $\mathrm{GI}_{50}$ concentration, as calculated from Supplementary Figure 1, and at equipotent concentrations at the same $\mathrm{GI}_{50}$ ratios in combination. Figure 1 shows that the combination of WX-037 and WX-554 was markedly more growth inhibitory than either compound alone, completely inhibiting growth at the highest concentrations. Data were then evaluated by median effect analysis (CalcuSyn, Biosoft, Great Shelford, UK) to determine whether the greater growth inhibitory activity of the combination of WX-554 and WX-037 reflected an additive or a synergistic effect. The combination of the PI3K inhibitor WX-037 and the MEK inhibitor WX-554 was strongly synergistic when combined

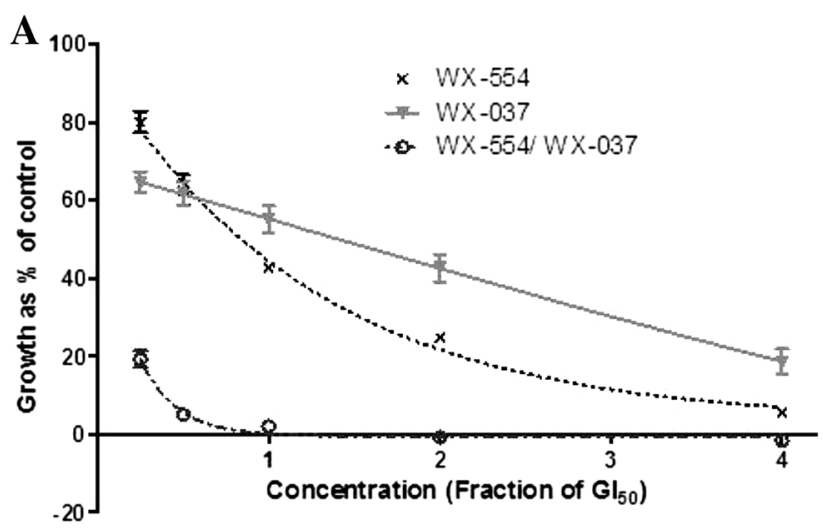

Fig. 1 Growth inhibition induced by the PI3K inhibitor WX-037 and the MEK inhibitor WX-554, alone and in combination, in the HCT116 and HT29 cell lines. HCT116 (a) and HT29 (b) cells were treated with the indicated fractions of the $\mathrm{GI}_{50}$ concentrations of the inhibitors, alone or in combination, derived from Supplementary at the $\mathrm{GI}_{50}$ concentration compared to the compounds alone (Supplementary Table 1).

Cell survival after 72-h exposure to the PI3K inhibitor WX-037 and the MEK inhibitor WX-554 was also measured using a clonogenic cytotoxicity assay. Single agent WX-554 showed significant cytotoxicity at $10 \mu \mathrm{M}$ with $67 \%$ cell kill in the HCT116 cell line and $75 \%$ in the HT29 cell line; however, the mean lethal concentration $\left(\mathrm{LC}_{50}\right)$ of $0.6 \mu \mathrm{M}$ and $1.6 \mu \mathrm{M} \mathrm{WX}-554$ was approximately 16 -fold and 372-fold higher than the corresponding $\mathrm{GI}_{50}$ - values in the HCT116 and HT29 cell lines, respectively. WX-037 showed no marked cytotoxicity with less than $50 \%$ cell death after $72 \mathrm{~h}$ treatment at $10 \mu \mathrm{M}$ (Supplementary Figure 2).

The cytotoxicity of the PI3K and MEK inhibitors in combination after $72 \mathrm{~h}$ treatment was then determined. However, as WX-037 did not produce $>50 \%$ cytotoxicity at $10 \mu \mathrm{M}$, it was not possible to determine an $\mathrm{LC}_{50}$ value, and hence the highest concentration previously used of $10 \mu \mathrm{M}$ WX-037 was combined with $10 \mu \mathrm{M}$ WX-554. There was a statistically significant increase in cytotoxicity when the PI3K and MEK inhibitors were combined, compared to the cytotoxicity induced by the drugs as single agents, in the HCT116 $(p=0.02)$ and HT29 $(p<0.01)$ cell lines (Fig. 2). Overall, the interaction of WX-037 and WX-554 resulted in significantly enhanced cell growth inhibition and an increase in cytotoxicity in both cell lines studied.

The effect of 24-h exposure to the PI3K inhibitor WX-037 and the MEK inhibitor WX-554, both as single agents and in combination, was also investigated by Western blotting to determine the effect on the PI3K/AKT signalling pathway, using total and phospho-specific antibodies for AKT, S6 and 4EBP1 and the effect on MAPK signalling, using total and phospho-specific antibodies for

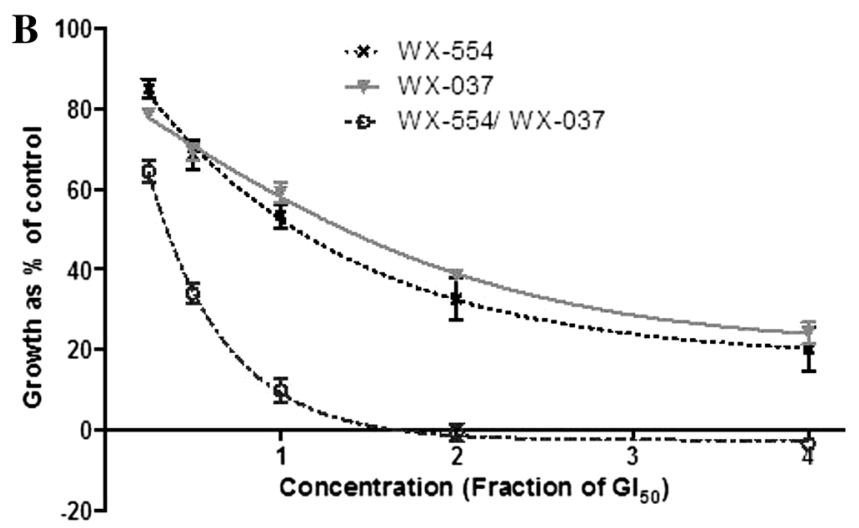

Figure 1, for $72 \mathrm{~h}$, and an SRB assay was subsequently performed. Growth is presented as a percentage of the control, in which cells were treated with $0.5 \%(\mathrm{v} / \mathrm{v})$ DMSO. Points represent the mean of 3 independent experiments \pm standard error. Lines were fitted using nonlinear regression analysis 


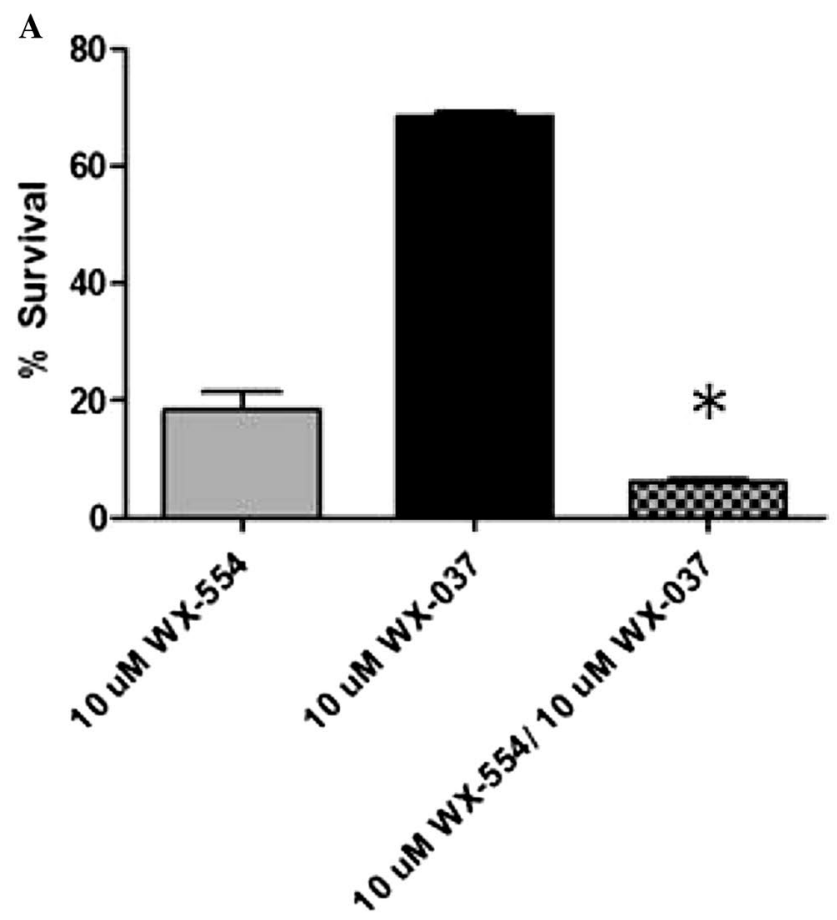

Fig. 2 Cell survival after 72 -h exposure to $10 \mu \mathrm{M}$ of the PI3K inhibitor WX-037 and $10 \mu \mathrm{M}$ of the MEK inhibitor WX-554, alone and in combination, in the HCT116 cell line and HT29 cell lines. HCT116 (a) and HT29 (b) cells were treated with a fixed concentration of each inhibitor alone or in combination for $72 \mathrm{~h}$, and cell survival was sub-

ERK1/2. The compounds were used as single agents or in combination at their respective $\mathrm{GI}_{50}$ concentrations and at $10 \mathrm{x}$ the $\mathrm{GI}_{50}$ concentration.

Supplementary Figure 3 shows that treatment with the MEK inhibitor WX-554 reduced ERK1/2 phosphorylation at 1 and 10 times the $\mathrm{GI}_{50}$ concentration in the HCT116 cell line, and at 10 times the $\mathrm{GI}_{50}$ concentration in the HT29 cell line. The reduction in ERK1/2 phosphorylation was enhanced with the combination of WX-554 and WX-037 leading to complete inhibition with 10 times the $\mathrm{GI}_{50}$ concentration in both colorectal carcinoma cell lines (Supplementary Figure 3). Additionally, there was a concentration-dependent reduction in AKT phosphorylation in the HCT116 cell line after treatment with the single agent PI3K inhibitor WX-037 which was enhanced, to yield complete inhibition at the $\mathrm{GI}_{50}$ concentration, after combined WX-037 and WX-554 treatment. In the HT29 cell line, there was a reduction in AKT phosphorylation at 10 times the $\mathrm{GI}_{50}$ concentration; however, this reduction was similar with single agent WX-037 and the combination (Supplementary Figure 3).

Single agent WX-037 also caused a concentrationdependent reduction in S6 phosphorylation at 1 and 10 times the $\mathrm{GI}_{50}$ concentration, and treatment with the combination of WX-037 and WX-554 enhanced this inhibition,

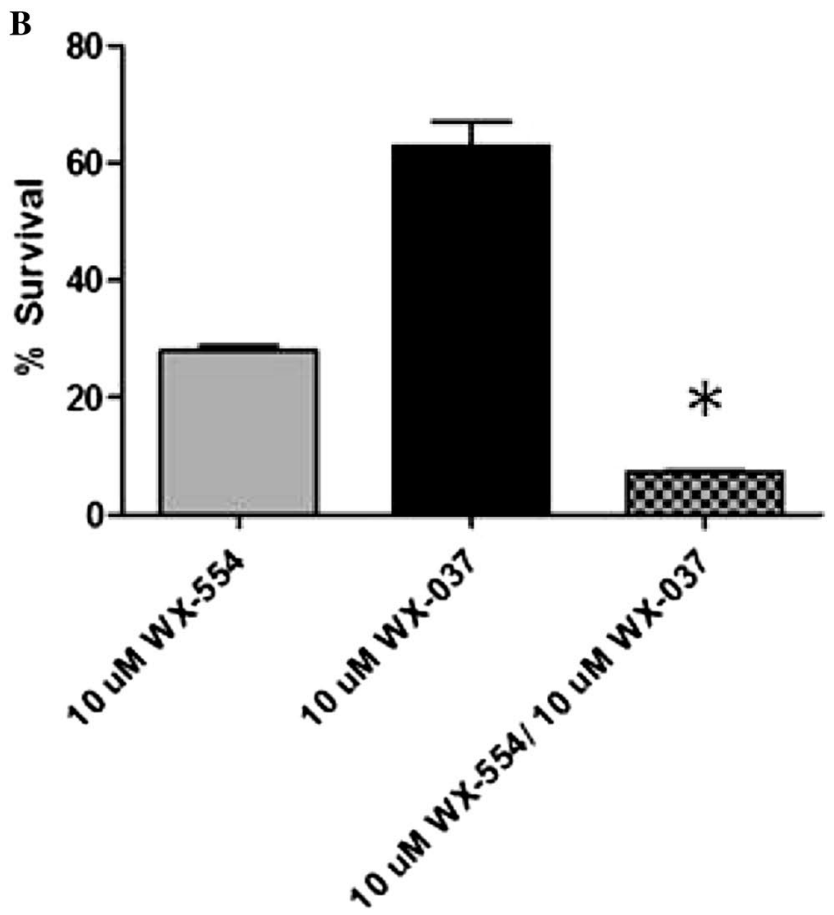

sequently determined by clonogenic assay after 10-14 days of colony growth. Survival is presented as a percentage of the control, in which cells were treated with $0.5 \%(\mathrm{v} / \mathrm{v})$ DMSO. Bars represent the mean of 3 independent replicates \pm standard error. *Significantly different from either agent alone, $p \leq 0.05$

causing complete inhibition at 10 times the $\mathrm{GI}_{50}$ concentration in both colorectal carcinoma cell lines (Supplementary Figure 3). However, WX-037 had no marked effect on the phosphorylation of 4EBP1 alone or in combination with WX-554 in either colorectal carcinoma cell line (Supplementary Figure 3). Hence, overall, the combination of the MEK inhibitor WX-554 and the PI3K inhibitor WX-037 resulted in enhanced inhibition of ERK1/2 and S6 phosphorylation, and inhibition of AKT phosphorylation, in both colorectal carcinoma cell lines. However, both the single agents and the combination had no major impact on 4EBP1 phosphorylation.

\section{The PI3K inhibitor WX-037 and the MEK inhibitor WX-554 exhibit increased tumour growth delay in combination in vivo}

A PK study was carried out with samples taken 6 and $24 \mathrm{~h}$ after treatment with a single dose of the PI3K inhibitor WX-037 and the MEK inhibitor WX-554, alone and in combination, in HCT116 and HT29 human tumour xenograft-bearing mice. The concentrations of the drugs in the plasma and the tumour tissue were measured using LCMS/MS (Figs. 3, 4, Supplementary Figures 4 and 5 and Supplementary Table 2). 

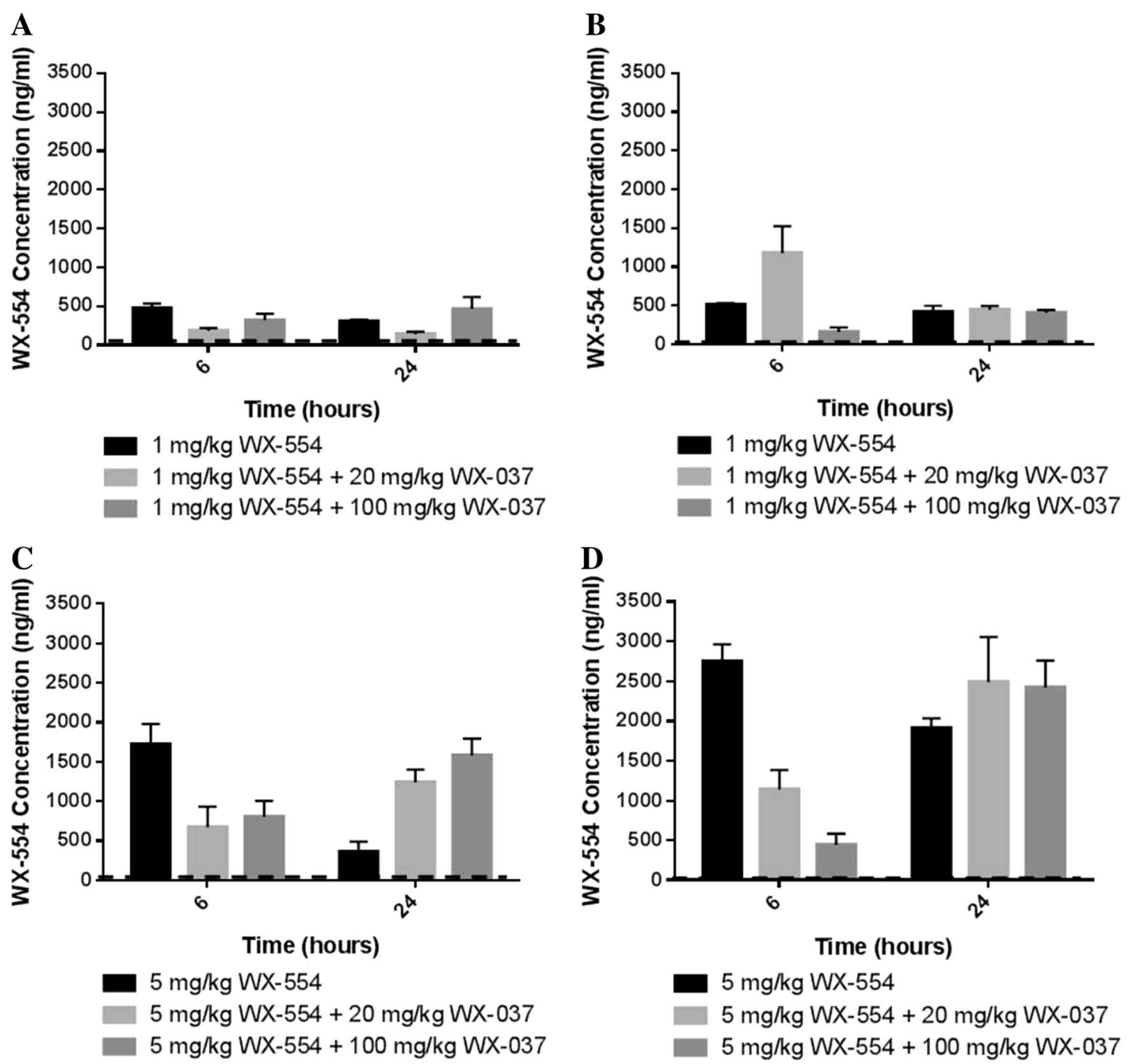

Fig. 3 Concentrations of the MEK inhibitor WX-554 alone and in combination with the PI3K inhibitor WX-037 in tumours from mice bearing HCT116 or HT29 human tumour xenografts. Tumour concentrations of WX-554 measured by LC-MS/MS from HCT116 (a, c) and HT29 (b, d) tumour xenograft-bearing mice at the indicated time points after a single p.o. dose of $1 \mathrm{mg} / \mathrm{kg}(\mathbf{a}, \mathbf{b})$ or $5 \mathrm{mg} / \mathrm{kg}(\mathbf{c}$,

d) WX-554 alone or combined with 20 or $100 \mathrm{mg} / \mathrm{kg} \mathrm{WX-037.} \mathrm{Data}$ are presented as the mean concentration from 3 mice in each group \pm standard error. Horizontal dashed lines indicate the in vitro $\mathrm{GI}_{50}$ concentration for the respective cell line, calculated from Supplementary Figure 1

After a single dose of 1 or $5 \mathrm{mg} / \mathrm{kg} \mathrm{WX}-554$, alone or in combination with 20 or $100 \mathrm{mg} / \mathrm{kg}$ WX-037, WX-554 concentrations in the plasma and tumour tissue generally greatly exceeded the in vitro $\mathrm{GI}_{50}$ value of $18 \mathrm{ng} / \mathrm{ml}$ (38 $\mathrm{nM})$ in the HCT116 cell line and $2 \mathrm{ng} / \mathrm{ml}(4 \mathrm{nM})$ in the HT29 cell line (determined in Supplementary Figure 1) (Fig. 3, Supplementary Figure 4 and Supplementary Table 2A). The exception to this was that plasma WX-554 concentrations were only approximately equal to the $\mathrm{HCT} 116 \mathrm{GI}_{50}$ value at $6 \mathrm{~h}$ and were below the HCT116 $\mathrm{GI}_{50}$ value by $24 \mathrm{~h}$, in the HCT116 tumour xenograft-bearing mice after treatment with $1 \mathrm{mg} / \mathrm{kg} \mathrm{WX-554,}$ alone or in combination with 20 or $100 \mathrm{mg} / \mathrm{kg} \mathrm{WX-037}$

(Supplementary Figure 4A and Supplementary Table 2A). Additionally, the plasma WX-554 concentration was also below the HCT116 $\mathrm{GI}_{50}$ value by $24 \mathrm{~h}$ after $5 \mathrm{mg} /$ kg WX-554 alone; however, WX-554 concentrations still exceeded the $\mathrm{GI}_{50}$ value when $5 \mathrm{mg} / \mathrm{kg} \mathrm{WX}-554$ was combined with WX-037 (Supplementary Figure 4C and Supplementary Table 2A). However, overall, the absolute plasma and tumour levels of WX-554 were generally similar in the HT29 and HCT116 tumour xenograft-bearing mice (Fig. 3, Supplementary Figure 4 and Supplementary Table 2A).

There was no consistent effect of concomitant dosing with 20 or $100 \mathrm{mg} / \mathrm{kg} \mathrm{WX-037} \mathrm{on} \mathrm{the} \mathrm{levels} \mathrm{of} \mathrm{WX-554}$ in the tumour or the plasma after administration of $1 \mathrm{mg} /$ 


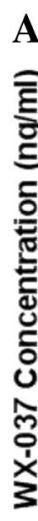

A

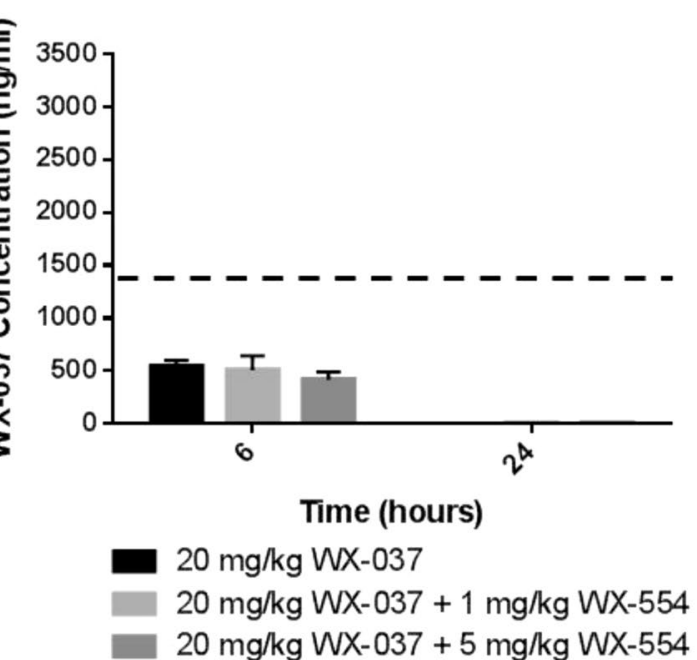

를

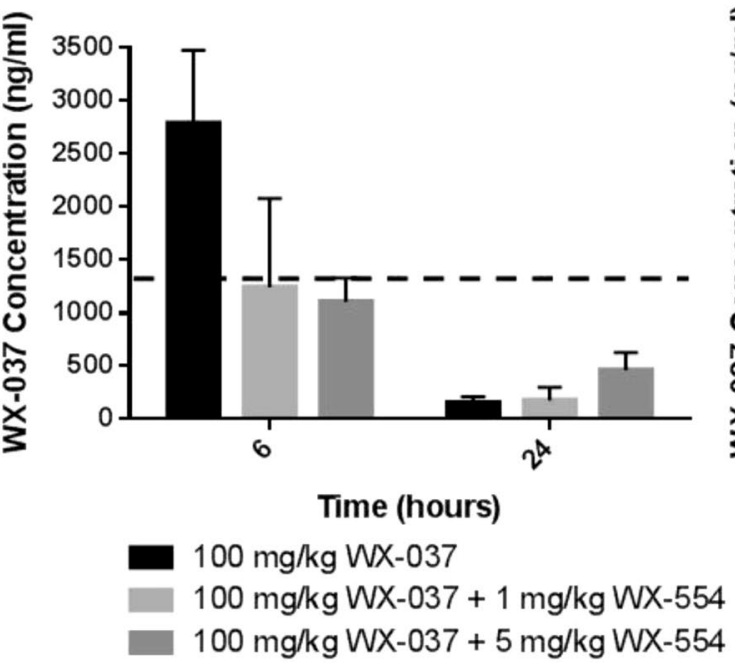

B
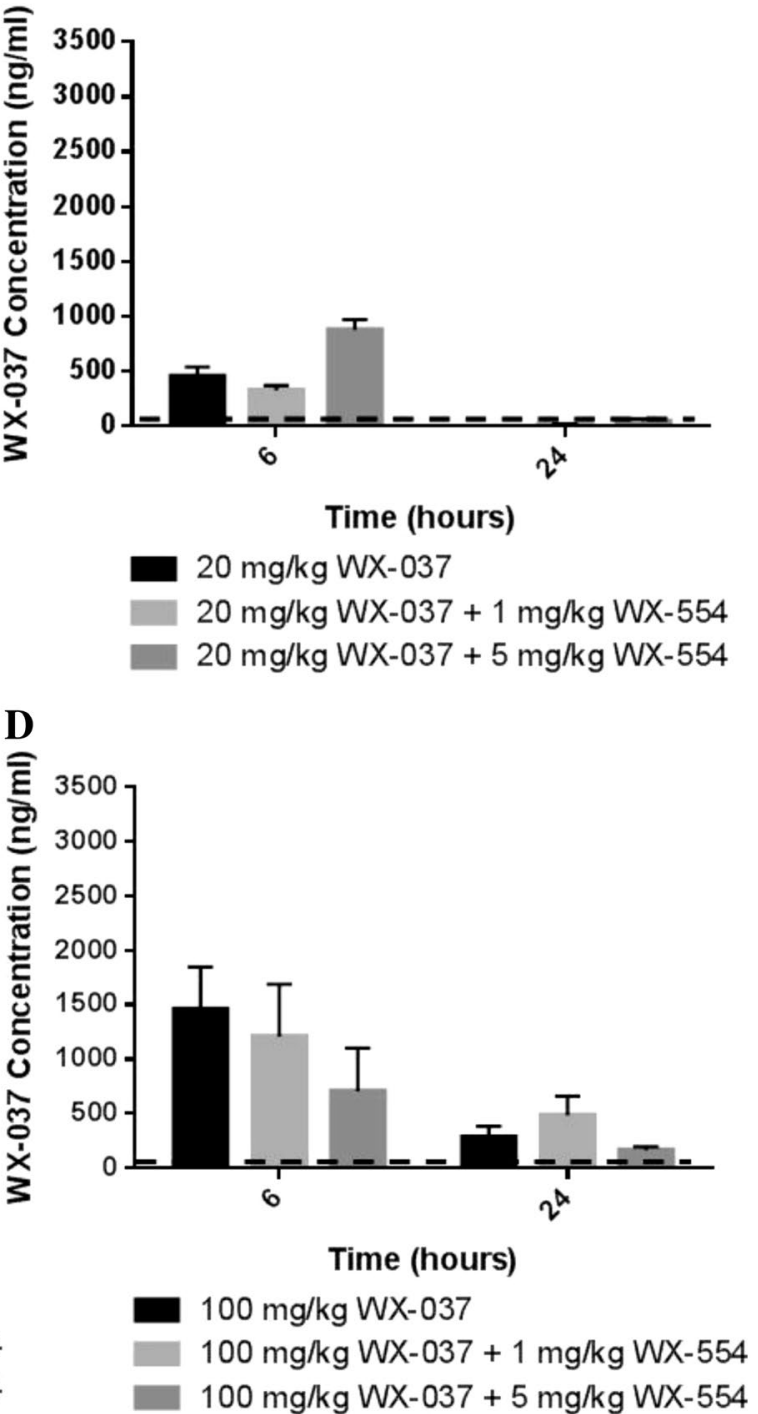

Fig. 4 Concentrations of the PI3K inhibitor WX-037 alone and in combination with the MEK inhibitor WX-554 in tumours from mice bearing HCT116 or HT29 human tumour xenografts. Tumour concentrations of WX-037 measured by LC-MS/MS from HCT116 (a, c) and HT29 (b, d) tumour xenograft-bearing mice at the indicated time points after a single p.o. dose of $20 \mathrm{mg} / \mathrm{kg}$ (a, b) or $100 \mathrm{mg} / \mathrm{kg}$

kg WX-554 in either HCT116 or HT29 tumour xenograft-bearing mice. In contrast, after dosing with $5 \mathrm{mg} / \mathrm{kg}$ WX-554, there was generally a WX-037 dose-dependent decrease in the levels of WX-554 at $6 \mathrm{~h}$ in the tumour and the plasma upon concomitant treatment with WX-037, which was significant for the tumour data at $6 \mathrm{~h}(p<0.05)$ (Fig. 3, Supplementary Figure 4 and Supplementary Table 2A). These results suggest that WX-037 may delay the tumour uptake of WX-554 at the higher dose $(5 \mathrm{mg} / \mathrm{kg})$ compared to when WX-554 is administered alone. (c, d) WX-037 alone or combined with 1 or $5 \mathrm{mg} / \mathrm{kg} \mathrm{WX-554.} \mathrm{Data}$ are presented as the mean concentration from 3 mice in each group \pm standard error. Horizontal dashed lines indicate the in vitro $\mathrm{GI}_{50}$ concentration for the respective cell line, calculated from Supplementary Figure 1

In contrast to the data for WX-554, after treatment

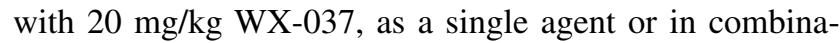
tion with 1 or $5 \mathrm{mg} / \mathrm{kg}$ WX-554, WX-037 concentrations in plasma and tumour tissue at 6 and $24 \mathrm{~h}$ were markedly lower than the in vitro $\mathrm{GI}_{50}$ value of $1414 \mathrm{ng} / \mathrm{ml}(2934 \mathrm{nM})$ in the HCT116 cell line (determined in Supplementary Figure 1) (Fig. 4a, Supplementary Figure 5A and Supplementary Table 2B). Plasma and tumour WX-037 concentrations were also markedly below the HCT116 $\mathrm{GI}_{50}$ value $24 \mathrm{~h}$ after treatment with $100 \mathrm{mg} / \mathrm{kg} \mathrm{WX}-037$, given as a single 
agent or in combination with 1 or $5 \mathrm{mg} / \mathrm{kg}$ WX-554; however, concentrations in the plasma and tumour tissue were similar to or exceeded the HCT116 GI G0 $_{50}$ value $6 \mathrm{~h}$ after a $100 \mathrm{mg} / \mathrm{kg}$ dose of WX-037 (Fig. 4c, Supplementary Figure $5 \mathrm{C}$ and Supplementary Table 2B).

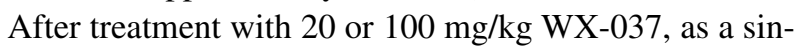

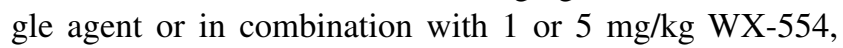
concentrations in plasma and tumour tissue greatly exceeded the in vitro $\mathrm{GI}_{50}$ value of $54 \mathrm{ng} / \mathrm{ml}(112 \mathrm{nM})$ in the HT29 cell line (determined in Supplementary Figure 1) at $6 \mathrm{~h}$. At $24 \mathrm{~h}$, although concentrations were similar to or exceeded the HT29 $\mathrm{GI}_{50}$ value in all tumour samples and in plasma after a $100 \mathrm{mg} / \mathrm{kg}$ dose of WX-037, plasma concentrations had generally declined to below the $\mathrm{GI}_{50}$ value after a $20 \mathrm{mg} / \mathrm{kg}$ dose of WX-037 (Fig. 4b-d, Supplementary Figure 5B and D and Supplementary Table 2B). As with the WX-554 data, the absolute plasma and tumour levels of WX-037 were similar in the HCT116 and HT29 tumour xenograft-bearing mice (Fig. 4, Supplementary Figure 5 and Supplementary Table 2B).

There did not appear to be a consistent effect of concomitant dosing with 1 or $5 \mathrm{mg} / \mathrm{kg} \mathrm{WX-554} \mathrm{on} \mathrm{the} \mathrm{levels}$ of WX-037 in the tumour or the plasma at $6 \mathrm{~h}$ after dosing with $20 \mathrm{mg} / \mathrm{kg}$ in either HCT116 or HT29 tumour xenograft-bearing mice (Fig. 4a, b, Supplementary Figure 5A and B and Supplementary Table 2B). However, after dosing with $100 \mathrm{mg} / \mathrm{kg}$, there appeared to be a dose-dependent decrease in the levels of WX-037 in the tumour and the plasma upon concomitant dosing with WX-554 at $6 \mathrm{~h}$, but this effect was only significant in HCT116 tumours (Fig. 4c, d, Supplementary Figure 5C and D and Supplementary Table 2B). Hence, concentrations of WX-037 were generally similar regardless of whether it was administered as a single agent or in combination with WX-554, and levels were consistently higher at $6 \mathrm{~h}$ compared with $24 \mathrm{~h}$.

As the combination of WX-554 and WX-037 was synergistic in the in vitro studies, it may not be necessary for the drug concentrations in the plasma and the tumour to exceed those of the in vitro $\mathrm{GI}_{50}$ values for the single agents to achieve efficacy with the combination in vivo. Based on the in vitro results, in order to achieve half maximal growth inhibition, less than $1 / 6$ th and approximately $1 / 3$ rd of the single agent $\mathrm{GI}_{50}$ was required for $50 \%$ growth inhibition with the drug combination in the HCT116 and HT29 cell lines, respectively, which equates to $\mathrm{GI}_{50}$ values of 3 and $<1 \mathrm{ng} / \mathrm{ml} \mathrm{WX-554}$ and 219 and $20 \mathrm{ng} / \mathrm{ml} \mathrm{WX-037} \mathrm{in}$ the HCT116 and HT29 cell lines (calculated from Fig. 1). Therefore, with all the combinations of WX-554 and WX-037, WX-554 levels in the plasma and tumour tissues are at or exceed the $\mathrm{GI}_{50}$ concentration for the combination at both 6 and 24 h (Fig. 3, Supplementary Figures 4 and Supplementary Table 2A). Furthermore, with all combinations of WX-554 and $100 \mathrm{mg} / \mathrm{kg}$ WX-037, WX-037 levels in the plasma and tumour tissues are at or exceed the $\mathrm{GI}_{50}$ for the combination at both 6 and $24 \mathrm{~h}$, and with all combinations of WX-554 with $20 \mathrm{mg} / \mathrm{kg}$ WX-037, WX-037 levels in the plasma and tumour tissues are at or exceed the $\mathrm{GI}_{50}$ for the combination at $6 \mathrm{~h}$, but remain below at $24 \mathrm{~h}$ (Fig. 4, Supplementary Figure 5 and Supplementary Table 2B).

Based on the results of the PK study, the efficacy of $50 \mathrm{mg} / \mathrm{kg}$ of the PI3K inhibitor WX-037 and $2 \mathrm{mg} / \mathrm{kg}$ of the MEK inhibitor WX-554 given orally, as single agents and in combination, was assessed in HCT116 human tumour xenograft-bearing mice (Fig. 5). The individual doses of the PI3K and MEK inhibitors were chosen to be approximately equiactive, in order to mirror the in vitro conditions under which synergy had been demonstrated (Supplementary Figure 1). In this study, mice were treated daily for 14 days and tumour volumes were measured three times a week. Figure 5 a demonstrates that treatment with $50 \mathrm{mg} / \mathrm{kg}$

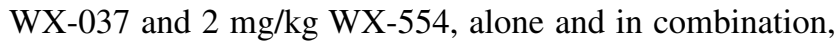
caused tumour growth delay compared to vehicle-treated control tumours, and that growth delay was greater with the combination. Additionally, body weight was monitored daily to assess the tolerability of the therapy, and both single agent and combination treatments were found to be well tolerated as average body weights did not drop below $89 \%$ of the starting weight (Fig. 5b). The time for the tumours to quadruple in size (time to RTV4) was calculated (Fig. 5c), and statistical analyses using a Mann-Whitney test demonstrated a significant difference between vehicle-treated control tumours and the combination group $(p<0.01)$, and between the single agent MEK inhibitor and the combination group $(p=0.02)$.

\section{Discussion}

The novel PI3K inhibitor WX-037 and the novel MEK inhibitor WX-554 have demonstrated in vitro activity in a range of cancer cell lines including breast, fibrosarcoma, thyroid, melanoma, colorectal, ovarian and pancreas lines with a broad range of $\mathrm{GI}_{50}$ values, where generally the cell lines most sensitive to WX-037 had PIK3CA mutations or PTEN loss, and to WX-554 had BRAF or RAS mutations [5]. Furthermore, the potency of WX-554 determined in the HCT116 and HT29 cell lines in this study (38 and $4.3 \mathrm{nM}$, respectively) was similar to that determined in the unpublished Wilex studies (29 and $7.2 \mathrm{nM}$ ) [5], and to the MEK inhibitor, PD 0325901 (21 and $6.5 \mathrm{nM}$ ) using the same assay [23]. Similarly the potency of WX-037 determined here in the HCT116 and HT29 cell lines (2934 and $112 \mathrm{nM}$, respectively) was similar to that reported in the unpublished Wilex studies (136 nM in the HT29 cell line) [5], and to the pan class I PI3K inhibitor, pictilisib (1081 and $157 \mathrm{nM}$ ) using the same assay [23]. 
A

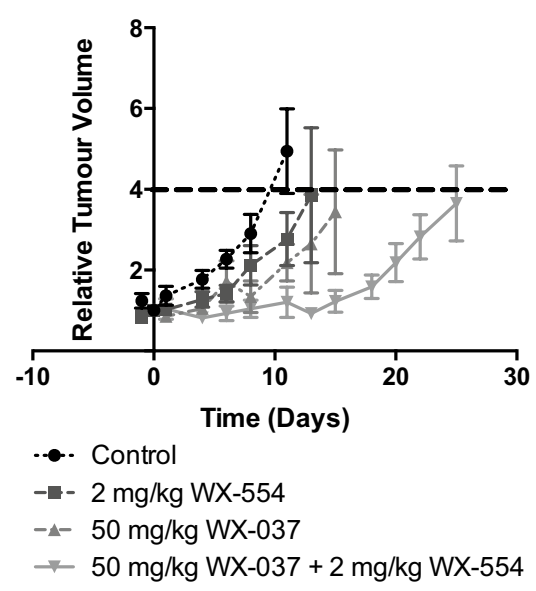

B

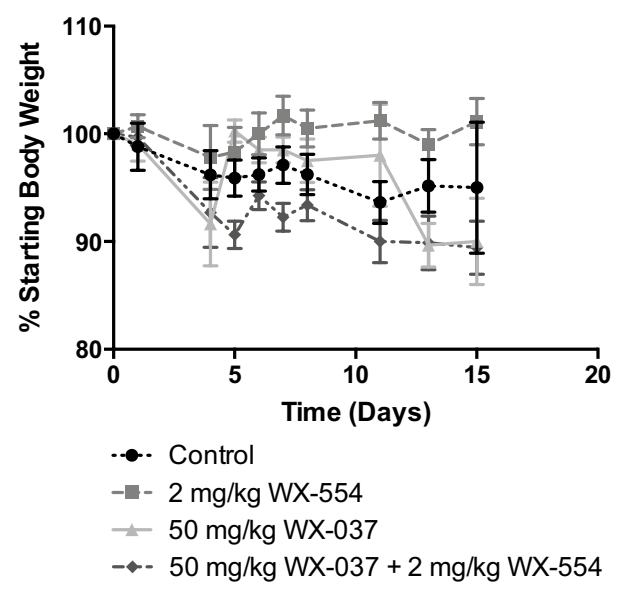

C

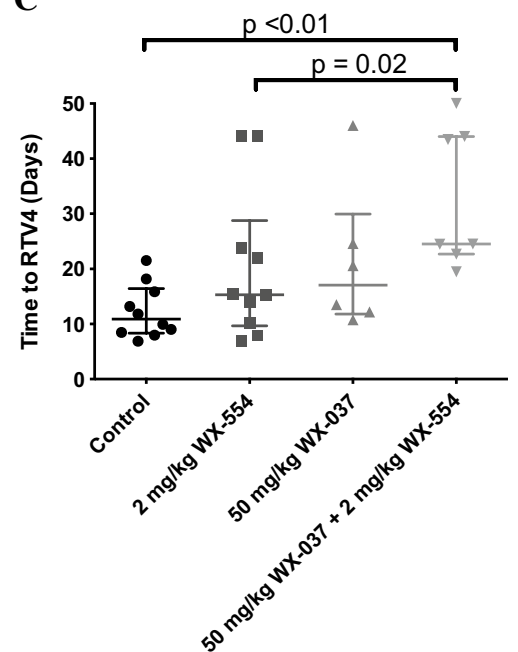

Fig. 5 Efficacy and tolerability of the PI3K inhibitor WX-037 and the MEK inhibitor WX-554 in mice bearing human HCT116 colorectal tumour xenografts. HCT116 tumour xenografts were treated with either vehicle control, $2 \mathrm{mg} / \mathrm{kg}$ of the MEK inhibitor WX-554 and $50 \mathrm{mg} / \mathrm{kg}$ of the PI3K inhibitor WX-037 alone, or $2 \mathrm{mg} / \mathrm{kg}$ of the MEK inhibitor WX-554 and $50 \mathrm{mg} / \mathrm{kg}$ of the PI3K inhibitor WX-037 in combination, p.o. once daily for 14 days. a Tumour growth curves: data are presented as the median relative tumour volume (RTV), where the growth is calculated for each tumour relative to its size on day 0 . Points represent the median of the 10 mice in each group. The

In these in vitro studies, the HT29 colorectal carcinoma cell line was consistently more sensitive to WX-037 and WX-554 than the HCT116 cell line (26 and 9-fold difference, respectively), which is consistent with other studies where the HT29 cell line exhibited increased sensitivity to pan class I PI3K and/or MEK inhibition, compared to the HCT116 cell line [23, 28, 29]. The observed difference could be due to the presence of a BRAF, rather than a KRAS, mutation as RAS mutations have been associated with intrinsic resistance in a previous study [30]. Alternatively, differences in cell signalling may be responsible, as sensitivity to MEK inhibition was found to correlate with strong ERK1/2 signalling and weak PI3K signalling [28]. Furthermore, the plethora of other mutations found in the HT29 and HCT116 cell lines may contribute to the difference in sensitivity [29, 31].

The combination of WX-037 and WX-554 was strongly synergistic, which is consistent with previous unpublished studies by UCB Celltech and Wilex where synergy was observed in the SK-MEL-28 melanoma, HT29 colorectal, Mia PaCa-2 pancreatic and SKOV-3 ovarian carcinoma cell lines [5]. The degree of synergy with the WX-037 and WX-554 combination was consistent with in vitro published studies using combinations of other PI3K and MEK inhibitors [2, 18, 23, 24, 32, 33]. dashed line shows the point at which tumours reached four times the initial volume (RTV4). b Effects on body weight: data are presented as a percentage of starting body weight. Points represent the mean of the mice in each group \pm standard error. $\mathbf{c}$ Time taken for xenografts to reach four times the initial volume (time to RTV4): data are presented as the time taken by each individual tumour in each group to quadruple in size, and lines to represent the mean of the mice in each group \pm standard error. $p$ values are given where the combination is significantly different from either agent alone $(p \leq 0.05)$

Single agent WX-554 not only exhibited growth inhibition but also significant cytotoxicity, albeit at higher concentrations with $\mathrm{LC}_{50}$ values approximately 16 -fold and 372 -fold higher than the corresponding $\mathrm{GI}_{50-}$ values in the HCT116 and HT29 cell lines, respectively. This marked cytotoxicity at $10 \mu \mathrm{M}$ is in contrast to the effect of PD 0325901 and selumetinib [23] and also to the general perspective that MEK inhibitors are cytostatic [34]. However, another study has already reported that selumetinib can cause apoptosis in some human tumour xenografts, but not in others, which was suggested to be due to differences in ERK1/2 substrate expression or differential cell signalling networks [35], and hence the result with WX-554 is not entirely unexpected.

In contrast to the effect of the MEK inhibitor, the PI3K inhibitor WX-037 at $10 \mu \mathrm{M}$ showed only limited cytotoxicity, which is consistent with the results observed with another pan class I PI3K inhibitor pictilisib [23]. However, the marked synergy observed in the growth inhibition studies with WX-037 and WX-554 translated into cytotoxicity, albeit at a high concentration $(10 \mu \mathrm{M})$, as there was a statistically significant increase in cytotoxicity with the combination of the Wilex PI3K and MEK inhibitors. This cytotoxicity is consistent with previous unpublished studies by UCB Celltech and Wilex where the observed growth 
inhibitory synergy with WX-037 and WX-554 in the SKMEL-28 melanoma, HT29 colorectal, Mia PaCa-2 pancreatic and SKOV-3 ovarian carcinoma cell lines was found to correlate with the induction of apoptosis [5]. Similarly, published in vitro studies have shown that combined inhibition of PI3K and MEK resulted in cell death [33, 36, 37].

Cell signalling studies showed that the single agent PI3K inhibitor WX-037 caused a concentration-dependent reduction in AKT and S6 phosphorylation, which was generally enhanced by the MEK inhibitor WX-554, but that 4EBP1 phosphorylation was not inhibited, consistent with the results of published studies using pan class I PI3K, as opposed to mixed PI3K/mTOR, inhibitors [23, 32, 37, 38]. Furthermore, single agent MEK inhibitor WX-554 caused a concentration-dependent reduction in ERK phosphorylation, and the combination of WX-554 and WX-037 resulted in enhanced inhibition of ERK1/2 phosphorylation, as observed with other MEK inhibitors [23, 39, 40] and combinations [23, 33].

In the pre-clinical studies presented here, and in both pre-clinical and clinical studies reported elsewhere [5, 6], WX-554 has been shown to be non-toxic. Furthermore, single agent WX-554 induced tumour growth delay at $2 \mathrm{mg} / \mathrm{kg}$ in HCT116 colorectal tumour xenograft models, consistent with previous unpublished studies using WX-554 and published studies using other MEK inhibitors that reported tumour growth delay or stasis in vivo, with increased sensitivity in BRAF or RAS mutant cells and tumours [3-5, 25]. In vivo pharmacokinetic analyses revealed concentrations of WX-554 in plasma and tumour tissue increased in a dose-dependent manner and that tumour WX-554 levels generally exceeded the in vitro $\mathrm{GI}_{50}$ concentration, whereas plasma levels were more variable.

Single agent WX-037 was also found to be non-toxic in these studies and those reported elsewhere [5, 17], which is consistent with data for other pan class I PI3K inhibitors [41-45]. Furthermore, $50 \mathrm{mg} / \mathrm{kg}$ WX-037 generated a tumour growth delay in HCT116 colorectal tumour xenograft models, which is consistent with previous unpublished studies using WX-037 and published studies using other pan class I PI3K inhibitors that reported tumour growth delay, or in some cases tumour stasis, with greater sensitivity in PIK3CA mutant or PTEN null cells and tumours [5, 14, 15, 46-51]. Pharmacokinetic studies indicated that concentrations of WX-037 in plasma and tumour tissue increased dose dependently and that WX-037 tumour and plasma levels generally exceeded the in vitro $\mathrm{GI}_{50}$ concentration at an early time point $(6 \mathrm{~h})$, depending on the cell line and dose, whereas levels generally had decreased below the $\mathrm{GI}_{50}$ value by the later time point $(24 \mathrm{~h})$. These pharmacokinetic data are similar to those observed in HCT116 tumour xenograft-bearing mice treated with pictilisib [25].
The PK analyses indicated that there was no pharmacokinetic interaction between WX-037 and WX-554 at lower doses. However, concomitant dosing of WX-037 with the high dose $(5 \mathrm{mg} / \mathrm{kg})$ of WX-554 caused a dose-dependent decrease in early time point $(6 \mathrm{~h}) \mathrm{WX}-554$ tumour and plasma concentrations, and a dose-dependent increase in late time point $(24 \mathrm{~h}) \mathrm{WX}-554$ levels, suggesting that the presence of WX-037 may delay the uptake of WX-554, leading to higher WX-554 levels at $24 \mathrm{~h}$. Furthermore, concomitant WX-554 dosing with high doses $(100 \mathrm{mg} / \mathrm{kg})$ of WX-037 caused a dose-dependent decrease in early time point $(6 \mathrm{~h}) \mathrm{WX}-037$ tumour and plasma concentrations; however, this effect was only significant in the HCT116 tumour tissue due to variation in the data. The pharmacokinetic interaction between higher doses of WX-037 and WX-554 is in contrast to the results obtained with the combination of PD 0325901 and pictilisib in HCT116 tumour xenograft-bearing mice [25], where there was no significant pharmacokinetic interaction, and to pre-clinical and clinical reports that there was no pharmacokinetic interaction between the PI3K and MEK inhibitors, pictilisib and cobimetinib [52, 53]. However, a recent Phase Ib study using a combination of the PI $3 \mathrm{~K}$ inhibitor buparlisib and the MEK inhibitor trametinib reported a potential pharmacokinetic interaction, which was suggested to be due to the variability of the accumulation of the MEK inhibitor as no clear mechanism could be identified [54].

In HCT116 colorectal tumour xenografts, the combination of $50 \mathrm{mg} / \mathrm{kg} \mathrm{WX-037} \mathrm{and} 2 \mathrm{mg} / \mathrm{kg}$ WX-554 was non-toxic and caused tumour stasis and enhanced tumour growth delay compared to either single agent at the same dose. This improved activity is consistent with previous studies using combinations of PI3K and MEK inhibitors in a range of pre-clinical human tumour xenograft and mouse models [19, 21, 22, 25, 55-58]. In a previous study using the MEK inhibitor, PD 0325901, and the PI3K inhibitor, GDC-0941, the cell line-dependent differences in sensitivity to the inhibitors determined in the in vitro studies did not correlate with the results observed in the in vivo studies $[23,25]$, suggesting that HT29 xenografts would not necessarily of been more sensitive to the inhibitors in vivo. Nevertheless, previous studies by UCB and Wilex have demonstrated that WX-554 treatment is able to induce tumour growth delay in HT29 xenografts [5].

The improved efficacy using combinations of PI3K and MEK inhibitors in pre-clinical studies is being translated into clinical trials $[45,54,59]$, and there are currently at least 7 ongoing or completed Phase $1 \mathrm{~b}$ clinical studies [9]. However, there have been issues with the tolerability of the combination treatment in two phase $1 \mathrm{~b}$ trials combining the MEK inhibitor trametinib, with either the pan-PI3K inhibitor buparlisib, or the PI3K/mTOR inhibitor GSK2126458, where the former study showed promising anti-tumour 
activity but frequent dose interruptions and reductions were necessary due to toxicity [54]. The latter study was terminated due to poor tolerability and efficacy $[9,60]$. These results suggest that the choice of the PI3K and MEK inhibitor to be combined will be crucial to the success of the treatment, due to subtle differences in the pharmacology of the inhibitors leading to differing toxicity profiles. Overall, these studies characterize, for the first time, the in vitro and in vivo efficacy of the PI3K inhibitor WX-037 and the MEK inhibitor WX-554, as single agents and in combination. Furthermore, these studies illustrate that dual targeting of PI3K and MEK can induce synergy in vitro which translates to marked tumour growth delay in vivo.

Acknowledgements The pharmacokinetic studies were performed by employees of Wilex.

Funding HDT, RJM and DRN are funded by a CRUK Drug Discovery Programme C240/A7409, and EJH was an MRC CASE Award PhD Student supported by UCB Celltech, Slough, United Kingdom.

\section{Compliance with ethical standards}

Conflict of interest Paul Bevan and Wolfgang Schmalix were employees of Wilex at the time that the research was conducted. Andrew Payne, Lara Kevorkian and Rodger Allen are employees of UCB Celltech, and Rodger Allen also consults for UCB Celltech.

Ethical approval All in vivo experiments were reviewed and approved by the Newcastle University (UK) animal welfare committee and were performed according to the guidelines for the welfare and use of animals in cancer research [27] and national law, under project license (PPL60/4442) issued by the UK Government Home Office under the animals (scientific procedure) act 1986.

Open Access This article is distributed under the terms of the Creative Commons Attribution 4.0 International License (http://creativecommons.org/licenses/by/4.0/), which permits unrestricted use, distribution, and reproduction in any medium, provided you give appropriate credit to the original author(s) and the source, provide a link to the Creative Commons license, and indicate if changes were made.

\section{References}

1. Hennig M, Yip-Schneider MT, Wentz S, Wu H, Hekmatyar SK, Klein P, Bansal N, Schmidt CM (2010) Targeting mitogenactivated protein kinase kinase with the inhibitor PD0325901 decreases hepatocellular carcinoma growth in vitro and in mouse model systems. Hepatology 51(4):1218-1225

2. Liu D, Xing M (2008) Potent Inhibition of thyroid cancer cells by the MEK Inhibitor PD0325901 and Its potentiation by suppression of the PI3K and NF-кB pathways. Thyroid 18(8):853864. doi: $10.1089 /$ thy. 2007.0357

3. Akinleye A, Furqan M, Mukhi N, Ravella P, Liu D (2013) MEK and the inhibitors: from bench to bedside. J Hematol Oncol 6:27

4. Templeton IE, Musib L (2015) MEK inhibitors beyond monotherapy: current and future development. Curr Opin Pharmacol 23:61-67. doi:10.1016/j.coph.2015.05.012
5. Wilex AG (unpublished data)

6. Mala C, Neville NG, Haindl E, Buergle M, Schmalix W, Bevan P (2010) A phase I, first-in-human single ascending dose study of the MEK inhibitor WX-554 given to healthy male subjects. J Clin Oncol 28((suppl; abstr)):e13666

7. Wilex AG (2012). http://www.wilex.de. Accessed 23/07/12

8. Miller CR, Oliver KE, Farley JH (2014) MEK1/2 inhibitors in the treatment of gynecologic malignancies. Gynecol Oncol 133(1):128-137. doi:10.1016/j.ygyno.2014.01.008

9. Clinical Trials gov (2016). http://clinicaltrials.gov/. Accessed 22/03/2016

10. Maira S-M, Stauffer F, Brueggen J, Furet P, Schnell C, Fritsch C, Brachmann S, Chene P, De Pover A, Schoemaker K, Fabbro D, Gabriel D, Simonen M, Murphy L, Finan P, Sellers W, Garcia-Echeverria C (2008) Identification and characterization of NVP-BEZ235, a new orally available dual phosphatidylinositol 3-kinase/mammalian target of rapamycin inhibitor with potent in vivo antitumor activity. Mol Cancer Ther 7(7):1851-1863. doi:10.1158/1535-7163.mct-08-0017

11. Serra V, Markman B, Scaltriti M, Eichhorn PJA, Valero V, Guzman M, Botero ML, Llonch E, Atzori F, Di Cosimo S, Maira M, Garcia-Echeverria C, Parra JL, Arribas J, Baselga J (2008) NVPBEZ235, a Dual PI3K/mTOR inhibitor, prevents PI3K signaling and inhibits the growth of cancer cells with activating PI3K mutations. Cancer Res 68(19):8022-8030. doi:10.1158/00085472.can-08-1385

12. Baumann P, Mandl-Weber S, Oduncu F, Schmidmaier R (2009) The novel orally bioavailable inhibitor of phosphoinositol-3-kinase and mammalian target of rapamycin, NVP-BEZ235, inhibits growth and proliferation in multiple myeloma. Exp Cell Res 315(3):485-497

13. Maira S-M, Stauffer F, Schnell C, Garcia-echeverria C (2009) PI3K inhibitors for cancer treatment: where do we stand? Biochem Soc Trans 37(1):265-272. doi:10.1042/bst0370265

14. Folkes AJ, Ahmadi K, Alderton WK, Alix S, Baker SJ, Box G, Chuckowree IS, Clarke PA, Depledge P, Eccles SA, Friedman LS, Hayes A, Hancox TC, Kugendradas A, Lensun L, Moore P, Olivero AG, Pang J, Patel S, Pergl-Wilson GH, Raynaud FI, Robson A, Saghir N, Salphati L, Sohal S, Ultsch MH, Valenti M, Wallweber HJA, Wan NC, Wiesmann C, Workman P, Zhyvoloup A, Zvelebil MJ, Shuttleworth SJ (2008) The Identification of 2-(1H-Indazol-4-yl)-6-(4-methanesulfonyl-piperazin-1-ylmethyl)-4-morpholin-4-yl-thieno[3,2-d]pyrimidine (GDC-0941) as a potent, selective, orally bioavailable inhibitor of class I PI3Kinase for the treatment of cancer. J Med Chem 51(18):5522-5532

15. Raynaud FI, Eccles SA, Patel S, Alix S, Box G, Chuckowree I, Folkes A, Gowan S, De Haven Brandon A, Di Stefano F, Hayes A, Henley AT, Lensun L, Pergl-Wilson G, Robson A, Saghir N, Zhyvoloup A, McDonald E, Sheldrake P, Shuttleworth S, Valenti M, Wan NC, Clarke PA, Workman P (2009) Biological properties of potent inhibitors of class I phosphatidylinositide 3-kinases: from PI-103 through PI-540, PI-620 to the oral agent GDC0941. Mol Cancer Ther 8(7):1725-1738. doi:10.1158/15357163.mct-08-1200

16. Mayer IA, Arteaga CL (2016) The PI3K/AKT pathway as a target for cancer treatment. Annu Rev Med 67:11-28. doi:10.1146/ annurev-med-062913-051343

17. Wilex AG (2013). http://www.wilex.de. Accessed 30/03/2016

18. Yu K, Toral-Barza L, Shi C, Zhang WG, Zask A (2008) Response and determinants of cancer cell susceptibility to PI3K inhibitors: combined targeting of PI3K and Mek1 as an effective anticancer strategy. Cancer Biol Ther 7(2):310-318

19. Engelman JA, Chen L, Tan X, Crosby K, Guimaraes AR, Upadhyay R, Maira M, McNamara K, Perera SA, Song Y, Chirieac LR, Kaur R, Lightbown A, Simendinger J, Li T, Padera RF, 
Garcia-Echeverria C, Weissleder R, Mahmood U, Cantley LC, Wong K-K (2008) Effective use of PI3K and MEK inhibitors to treat mutant Kras G12D and PIK3CA H1047R murine lung cancers. Nat Med 14(12):1351-1356

20. Jokinen E, Koivunen JP (2015) MEK and PI3K inhibition in solid tumors: rationale and evidence to date. Ther Adv Med Oncol 7(3):170-180. doi:10.1177/1758834015571111

21. Sos ML, Fischer S, Ullrich R, Peifer M, Heuckmann JM, Koker M, Heynck S, Stückrath I, Weiss J, Fischer F, Michel K, Goel A, Regales L, Politi KA, Perera S, Getlik M, Heukamp LC, Ansén S, Zander T, Beroukhim R, Kashkar H, Shokat KM, Sellers WR, Rauh D, Orr C, Hoeflich KP, Friedman L, Wong KK, Pao W, Thomas RK (2009) Identifying genotype-dependent efficacy of single and combined PI3K- and MAPK-pathway inhibition in cancer. Proc Nat Acad Sci USA 106(43):18351-18356

22. Hoeflich KP, Merchant M, Orr C, Chan J, Den Otter D, Berry L, Kasman I, Koeppen H, Rice K, Yang N-Y, Engst S, Johnston S, Friedman LS, Belvin M (2012) Intermittent administration of MEK inhibitor GDC-0973 plus PI3K inhibitor GDC-0941 triggers robust apoptosis and tumor growth inhibition. Cancer Res 72(1):210-219. doi:10.1158/0008-5472.can-11-1515

23. Haagensen EJ, Kyle S, Beale GS, Maxwell RJ, Newell DR (2012) The synergistic interaction of MEK and PI3K inhibitors is modulated by mTOR inhibition. Br J Cancer 106(8):1386-1394

24. Haagensen EJ, Thomas HD, Mudd C, Tsonou E, Wiggins CM, Maxwell RJ, Moore JD, Newell DR (2016) Pre-clinical use of isogenic cell lines and tumours in vitro and in vivo for predictive biomarker discovery; impact of KRAS and PI3KCA mutation status on MEK inhibitor activity is model dependent. Eur J Cancer (Oxford, England: 1990) 56:69-76. doi:10.1016/j. ejca.2015.12.012

25. Haagensen EJ, Thomas HD, Wilson I, Harnor SJ, Payne SL, Rennison T, Smith KM, Maxwell RJ, Newell DR (2013) The enhanced in vivo activity of the combination of a MEK and a PI3K inhibitor correlates with [18F]-FLT PET in human colorectal cancer xenograft tumour-bearing mice. PLoS ONE 8(12):e81763. doi:10.1371/journal.pone.0081763

26. Britten CD (2013) PI3K and MEK inhibitor combinations: examining the evidence in selected tumor types. Cancer Chemother Pharmacol 71(6):1395-1409. doi:10.1007/s00280-013-2121-1

27. Workman P, Aboagye EO, Balkwill F, Balmain A, Bruder G, Chaplin DJ, Double JA, Everitt J, Farningham DAH, Glennie MJ, Kelland LR, Robinson V, Stratford IJ, Tozer GM, Watson S, Wedge SR, Eccles SA (2010) Guidelines for the welfare and use of animals in cancer research. Br J Cancer 102(11):1555-1577

28. Balmanno K, Chell SD, Gillings AS, Hayat S, Cook SJ (2009) Intrinsic resistance to the MEK1/2 inhibitor AZD6244 (ARRY142886) is associated with weak ERK1/2 signalling and/or strong PI3K signalling in colorectal cancer cell lines. Int J Cancer 125(10):2332-2341. doi:10.1002/ijc.24604

29. Genomics of Drug Sensitivity in Cancer (2012). http://www.cancerrxgene.org/. Accessed 05/10/2012

30. Ebi H, Corcoran RB, Singh A, Chen Z, Song Y, Lifshits E, Ryan DP, Meyerhardt JA, Benes C, Settleman J, Wong K-K, Cantley LC, Engelman JA (2011) Receptor tyrosine kinases exert dominant control over PI3K signaling in human KRAS mutant colorectal cancers. J Clin Investig 121(11):4311-4321. doi:10.1172/jci57909

31. Garnett MJ, Edelman EJ, Heidorn SJ, Greenman CD, Dastur A, Lau KW, Greninger P, Thompson IR, Luo X, Soares J, Liu Q, Iorio F, Surdez D, Chen L, Milano RJ, Bignell GR, Tam AT, Davies H, Stevenson JA, Barthorpe S, Lutz SR, Kogera F, Lawrence K, McLaren-Douglas A, Mitropoulos X, Mironenko T, Thi H, Richardson L, Zhou W, Jewitt F, Zhang T, O'Brien P, Boisvert JL, Price S, Hur W, Yang W, Deng X, Butler A, Choi HG, Chang JW, Baselga J, Stamenkovic I, Engelman JA, Sharma SV, Delattre O, Saez-Rodriguez J, Gray NS, Settleman J, Futreal PA,
Haber DA, Stratton MR, Ramaswamy S, McDermott U, Benes $\mathrm{CH}$ (2012) Systematic identification of genomic markers of drug sensitivity in cancer cells. Nature 483(7391):570-575

32. Pitts TM, Newton TP, Bradshaw-Pierce EL, Addison R, Arcaroli JJ, Klauck PJ, Bagby SM, Hyatt SL, Purkey A, Tentler JJ, Tan AC, Messersmith WA, Eckhardt SG, Leong S (2014) Dual pharmacological targeting of the MAP kinase and PI3K/mTOR pathway in preclinical models of colorectal cancer. PLoS ONE 9(11):e113037. doi:10.1371/journal.pone.0113037

33. Ku BM, Jho EH, Bae YH, Sun JM, Ahn JS, Park K, Ahn MJ (2015) BYL719, a selective inhibitor of phosphoinositide 3-Kinase alpha, enhances the effect of selumetinib (AZD6244, ARRY-142886) in KRAS-mutant non-small cell lung cancer. Invest New Drugs 33(1):12-21. doi:10.1007/s10637-014-0163-9

34. Kohno M, Pouyssegur J (2006) Targeting the ERK signaling pathway in cancer therapy. Ann Med 38(3):200-211

35. Davies BR, Logie A, McKay JS, Martin P, Steele S, Jenkins R, Cockerill M, Cartlidge S, Smith PD (2007) AZD6244 (ARRY142886), a potent inhibitor of mitogen-activated protein kinase/ extracellular signal-regulated kinase kinase 1/2 kinases: mechanism of action in vivo, pharmacokinetic/pharmacodynamic relationship, and potential for combination in preclinical models. Mol Cancer Ther 6(8):2209-2219. doi:10.1158/1535-7163. mct-07-0231

36. Wee S, Jagani Z, Xiang KX, Loo A, Dorsch M, Yao Y-M, Sellers WR, Lengauer C, Stegmeier F (2009) PI3K pathway activation mediates resistance to MEK inhibitors in KRAS mutant cancers. Cancer Res 69(10):4286-4293. doi:10.1158/0008-5472. can-08-4765

37. Edgar KA, Wallin JJ, Berry M, Lee LB, Prior WW, Sampath D, Friedman LS, Belvin M (2010) Isoform-specific phosphoinositide 3-kinase inhibitors exert distinct effects in solid tumors. Cancer Res 70(3):1164-1172. doi:10.1158/0008-5472. can-09-2525

38. Santiskulvong C, Konecny GE, Fekete M, Chen K-YM, Karam A, Mulholland D, Eng C, Wu H, Song M, Dorigo O (2011) Dual targeting of phosphoinositide 3-kinase and mammalian target of rapamycin Using NVP-BEZ235 as a novel therapeutic approach in human ovarian carcinoma. Clin Cancer Res 17(8):2373-2384. doi:10.1158/1078-0432.ccr-10-2289

39. Haura EB, Ricart AD, Larson TG, Stella PJ, Bazhenova L, Miller VA, Cohen RB, Eisenberg PD, Selaru P, Wilner KD, Gadgeel SM (2010) A phase II study of PD-0325901, an Oral MEK inhibitor, in previously treated patients with advanced non-small cell lung cancer. Clin Cancer Res 16(8):2450-2457. doi:10.1158/10780432.ccr-09-1920

40. Yeh TC, Marsh V, Bernat BA, Ballard J, Colwell H, Evans RJ, Parry J, Smith D, Brandhuber BJ, Gross S, Marlow A, Hurley B, Lyssikatos J, Lee PA, Winkler JD, Koch K, Wallace E (2007) Biological characterization of ARRY-142886 (AZD6244), a potent, highly selective mitogen-activated protein kinase kinase 1/2 inhibitor. Clin Cancer Res 13(5):1576-1583. doi:10.1158/1078-0432.ccr-06-1150

41. Yap TA, Bjerke L, Clarke PA, Workman P (2015) Drugging PI3K in cancer: refining targets and therapeutic strategies. Curr Opin Pharmacol 23:98-107. doi:10.1016/j.coph.2015.05.016

42. Sarker D, Ang JE, Baird R, Kristeleit R, Shah K, Moreno V, Clarke PA, Raynaud FI, Levy G, Ware JA, Mazina K, Lin R, Wu J, Fredrickson J, Spoerke JM, Lackner MR, Yan Y, Friedman LS, Kaye SB, Derynck MK, Workman P, de Bono JS (2015) Firstin-human phase I study of pictilisib (GDC-0941), a potent panclass I phosphatidylinositol-3-kinase (PI3K) inhibitor, in patients with advanced solid tumors. Clin Cancer Res 21(1):77-86. doi:10.1158/1078-0432.ccr-14-0947

43. Bendell JC, Rodon J, Burris HA, de Jonge M, Verweij J, Birle D, Demanse D, De Buck SS, Ru QC, Peters M, Goldbrunner M, 
Baselga J (2012) Phase I, dose-escalation study of BKM120, an oral pan-Class I PI3K inhibitor, in patients with advanced solid tumors. J Clin Oncol 30(3):282-290. doi:10.1200/ jco.2011.36.1360

44. Hong DS, Bowles DW, Falchook GS, Messersmith WA, George GC, O'Bryant CL, Vo AC, Klucher K, Herbst RS, Eckhardt SG, Peterson S, Hausman DF, Kurzrock R, Jimeno A (2012) A multicenter phase I trial of PX-866, an oral irreversible phosphatidylinositol 3-kinase inhibitor, in patients with advanced solid tumors. Clin Cancer Res 18(15):4173-4182. doi:10.1158/10780432.ccr-12-0714

45. Shapiro GI, Rodon J, Bedell C, Kwak EL, Baselga J, Brana I, Pandya SS, Scheffold C, Laird AD, Nguyen LT, Xu Y, Egile C, Edelman G (2014) Phase I safety, pharmacokinetic, and pharmacodynamic study of SAR245408 (XL147), an oral pan-class I PI3K inhibitor, in patients with advanced solid tumors. Clin Cancer Res 20(1):233-245. doi:10.1158/1078-0432.ccr-13-1777

46. Foster P, Yamaguchi K, Hsu PP, Qian F, Du X, Wu J, Won KA, Yu P, Jaeger CT, Zhang W, Marlowe CK, Keast P, Abulafia W, Chen J, Young J, Plonowski A, Yakes FM, Chu F, Engell K, Bentzien F, Lam ST, Dale S, Yturralde O, Matthews DJ, Lamb P, Laird AD (2015) The selective PI3K inhibitor XL147 (SAR245408) inhibits tumor growth and survival and potentiates the activity of chemotherapeutic agents in preclinical tumor models. Mol Cancer Ther 14(4):931-940. doi:10.1158/1535-7163.mct-14-0833

47. Burger MT, Pecchi S, Wagman A, Ni ZJ, Knapp M, Hendrickson T, Atallah G, Pfister K, Zhang Y, Bartulis S, Frazier K, Ng S, Smith A, Verhagen J, Haznedar J, Huh K, Iwanowicz E, Xin X, Menezes D, Merritt H, Lee I, Wiesmann M, Kaufman S, Crawford K, Chin M, Bussiere D, Shoemaker K, Zaror I, Maira SM, Voliva CF (2011) Identification of NVP-BKM120 as a potent, selective, orally bioavailable class I PI3 kinase inhibitor for treating cancer. ACS Med Chem Lett 2(10):774-779. doi:10.1021/ $\mathrm{ml} 200156 \mathrm{t}$

48. Ohwada J, Ebiike H, Kawada H, Tsukazaki M, Nakamura M, Miyazaki T, Morikami K, Yoshinari K, Yoshida M, Kondoh O, Kuramoto S, Ogawa K, Aoki Y, Shimma N (2011) Discovery and biological activity of a novel class I PI3K inhibitor, CH5132799. Bioorg Med Chem Lett 21(6):1767-1772. doi:10.1016/j. bmcl.2011.01.065

49. Liu N, Rowley BR, Bull CO, Schneider C, Haegebarth A, Schatz CA, Fracasso PR, Wilkie DP, Hentemann M, Wilhelm SM, Scott WJ, Mumberg D, Ziegelbauer K (2013) BAY 80-6946 is a highly selective intravenous PI3K inhibitor with potent p110alpha and p110delta activities in tumor cell lines and xenograft models. Mol Cancer Ther 12(11):2319-2330. doi:10.1158/1535-7163. mct-12-0993-t

50. Ihle NT, Williams R, Chow S, Chew W, Berggren MI, PaineMurrieta G, Minion DJ, Halter RJ, Wipf P, Abraham R, Kirkpatrick L, Powis G (2004) Molecular pharmacology and antitumor activity of PX-866, a novel inhibitor of phosphoinositide-3-kinase signaling. Mol Cancer Ther 3(7):763-772

51. Kong D, Yamori $T$ (2009) Advances in development of phosphatidylinositol 3-kinase inhibitors. Curr Med Chem 16(22):2839-2854

52. Shapiro G, LoRusso P, Kwak EL, Cleary JM, Musib L, Jones C, de Crespigny A, Belvin M, McKenzie M, Gates MR, Chan IT, Bendell JC (2011) Clinical combination of the MEK inhibitor
GDC-0973 and the PI3K inhibitor GDC-0941: a first-in-human phase Ib study testing daily and intermittent dosing schedules in patients with advanced solid tumors. J Clin Oncol 29((suppl; abstr)):3005

53. Choo EF, Ng CM, Berry L, Belvin M, Lewin-Koh N, Merchant M, Salphati L (2013) PK-PD modeling of combination efficacy effect from administration of the MEK inhibitor GDC-0973 and PI3K inhibitor GDC-0941 in A2058 xenografts. Cancer Chemother Pharmacol 71(1):133-143. doi:10.1007/ s00280-012-1988-6

54. Bedard PL, Tabernero J, Janku F, Wainberg ZA, Paz-Ares L, Vansteenkiste J, Van Cutsem E, Perez-Garcia J, Stathis A, Britten CD, Le N, Carter K, Demanse D, Csonka D, Peters M, Zubel A, Nauwelaerts H, Sessa C (2015) A phase Ib dose-escalation study of the oral pan-PI3K inhibitor buparlisib (BKM120) in combination with the oral MEK1/2 inhibitor trametinib (GSK1120212) in patients with selected advanced solid tumors. Clin Cancer Res 21(4):730-738. doi:10.1158/1078-0432.ccr-14-1814

55. Roper J, Sinnamon MJ, Coffee EM, Belmont P, Keung L, Georgeon-Richard L, Wang WV, Faber AC, Yun J, Yilmaz OH, Bronson RT, Martin ES, Tsichlis PN, Hung KE (2014) Combination $\mathrm{PI} 3 \mathrm{~K} / \mathrm{MEK}$ inhibition promotes tumor apoptosis and regression in PIK3CA wild-type KRAS mutant colorectal cancer. Cancer Lett 347(2):204-211. doi:10.1016/j.canlet.2014.02.018

56. Martinelli E, Troiani T, D'Aiuto E, Morgillo F, Vitagliano D, Capasso A, Costantino S, Ciuffreda LP, Merolla F, Vecchione L, De Vriendt V, Tejpar S, Nappi A, Sforza V, Martini G, Berrino L, De Palma R, Ciardiello F (2013) Antitumor activity of pimasertib, a selective MEK $1 / 2$ inhibitor, in combination with $\mathrm{PI} 3 \mathrm{~K} / \mathrm{mTOR}$ inhibitors or with multi-targeted kinase inhibitors in pimasertib-resistant human lung and colorectal cancer cells. Int J Cancer 133(9):2089-2101. doi:10.1002/ijc.28236

57. Kinross KM, Brown DV, Kleinschmidt M, Jackson S, Christensen J, Cullinane C, Hicks RJ, Johnstone RW, McArthur GA (2011) In vivo activity of combined PI3K/mTOR and MEK Inhibition in a KrasG12D; Pten deletion mouse model of ovarian cancer. Mol Cancer Ther 10(8):1440-1449. doi:10.1158/15357163.mct-11-0240

58. Faber AC, Li D, Song Y, Liang M-C, Yeap BY, Bronson RT, Lifshits E, Chen Z, Maira S-M, Garcia-Echeverria C, Wong K-K, Engelman JA (2009) Differential induction of apoptosis in HER2 and EGFR addicted cancers following PI3K inhibition. Proc Nat Acad Sci 106(46):19503-19508. doi:10.1073/pnas.0905056106

59. Shimizu T, Tolcher AW, Papadopoulos KP, Beeram M, Rasco DW, Smith LS, Gunn S, Smetzer L, Mays TA, Kaiser B, Wick MJ, Alvarez C, Cavazos A, Mangold GL, Patnaik A (2012) The clinical effect of the dual-targeting strategy involving $\mathrm{PI} 3 \mathrm{~K} / \mathrm{AKT} / \mathrm{mTOR}$ and RAS/MEK/ERK pathways in patients with advanced cancer. Clin Cancer Res 18(8):2316-2325. doi:10.1158/1078-0432.ccr-11-2381

60. Grilley-Olson JE, Bedard PL, Fasolo A, Cornfeld M, Cartee L, Razak AR, Stayner LA, Wu Y, Greenwood R, Singh R, Lee CB, Bendell J, Burris HA, Del Conte G, Sessa C, Infante JR (2016) A phase $\mathrm{Ib}$ dose-escalation study of the MEK inhibitor trametinib in combination with the PI3K/mTOR inhibitor GSK2126458 in patients with advanced solid tumors. Invest New Drugs. doi:10.1007/s10637-016-0377-0 